\title{
Joseph Lancaster in Montreal (bis): Monitorial Schooling and Politics in a Colonial Context ${ }^{1}$
}

\author{
Bruce Curtis
}

The residence of the English promoter of monitorial schooling, Joseph Lancaster, from late summer 1829 to early spring 1833 at Montreal, in the British North American colony of Lower Canada, was the subject of a 1941 essay by G.W. Spragge. This reprise of Spragge's work uses additional materials to locate Lancaster and monitorial schooling in the context of contemporary politics and educational policy.

En 1941, G. W. Spragge écrivit un essai sur la présence à Montréal, entre la fin de l'été 1829 jusqu'au début du printemps 1833, de Joseph Lancaster, le promoteur anglais du système d'instruction dit « monitorial ». Cet article se veut une reprise du travail de Spragge. Nous nous appuyons sur une documentation nouvelle pour situer Lancaster et son système d'instruction dans le contexte politique et éducatif de l'époque.

From late summer 1829 until the spring of 1833, the quixotic Quaker educator, Joseph Lancaster, partisan and co-inventor of the monitorial school, lived in Montreal, Lower Canada, and involved himself in school management and in educational and medical politics. In the considerable literature devoted to Lancaster himself and to monitorial schooling, the period in Montreal figures only as a minor episode in a troubled life and as a footnote to the spread of the monitorial method across Europe and North and South America. Such is the portrayal offered even in "Joseph Lancaster in Montreal," a 1941 article by the historian and future archivist of Ontario, George Spragge. While Spragge had offered extensive coverage of the organization of monitorial schooling in British North America in his unpublished doctoral dissertation, neither there, nor in his article, did he attempt to locate Lancaster in the context of

1 Research for this article was supported by the Social Sciences and Humanities Research Council of Canada. I am grateful for the research assistance of Robyn Smith and J.-F. Constant as well as for the constructive criticism of the journal's reviewers.

(CHistorical Studies in Education / Revue d'histoire de l'éducation 17, 1 (2005): 1-27 
contemporary politics or to draw on sources other than Lancaster's own version of the controversial events that led him to leave the city. ${ }^{2}$

Beyond the educational history literature, Lancaster also appears as a minor figure in the literature on the 1832 cholera; there, however, there is no discussion of his educational credentials. Geoffrey Bilson's cholera history, for instance, makes passing mention of Lancaster in his account of the Montreal epidemic, identifying him only as a "controversialist." Yet Lancaster acted as the agent and promoter of the notorious American cholera doctor, Stephen Ayres, who opened an office next to Lancaster's house shortly after his arrival in Montreal in June $1832 .{ }^{3}$ While in his own account of his residence in Montreal Lancaster mentioned only that the cholera led him to close his school for a time, his cholera-related activities not only intensified clerical antipathy to him, but reinforced suspicions in the French-language radical press about his morals and politics. Ayres' medical quackery and Lancaster's educational quackery seemed on a par to many observers.

For historians of education in Canada as well as for historians of monitorial schooling generally, Lancaster's Lower Canadian activities merit additional attention. He arrived in the colony at just the moment when the colonial government was moving to establish a rural elementary school system. There was a burst of public discussion and debate over the best methods for educating large numbers of young people that exposed readers to detailed discussion of pedagogical practices and to international educational developments. Many Lower Canadian readers and writers, in common with their American and European contemporaries, were more or less mystified by the notion of "educational system" that figured centrally in such discussions. The concept carried connotations of the efficient machining of new members of society, just as the nascent factory system was machining masses of commodities. For some at least, it also implied a rending of closely knit social hierarchies, the determined undermining of established rules of comportment, and the production of youth committed to "liberalism - the modern fashionable word for Atheism." 4

Joseph Lancaster was a catalyst for educational debate and discussion. He quickly attracted the enthusiastic support of leading members of the colony's increasingly powerful patriote party, the

2 George W. Spragge, “Monitorial Schools in the Canadas, 1810-1845” (D.Paed. diss., University of Toronto, 1935); and "Joseph Lancaster in Montreal," Canadian Historical Review XXII (1941): 35-41. George Spragge was probably a descendant of Joseph Spragge, master of the York Central School, a monitorial institution of the 1810s. Only one monograph treats monitorial schooling in Canada extensively: J.-J. Jolois, Joseph-François Perrault (1753-1844) et les origines de l'enseignement laïque au BasCanada (Montréal: Les Presses de l'Université de Montréal, 1969). See also Heather Lysons-Balcon, “Lancaster, Joseph,” Dictionary of Canadian Biography VI: 481-83.

3 Geoffrey Bilson, A Darkened House: Cholera in Nineteenth Century Canada (Toronto: University of Toronto Press, 1980), 31.

4 “P," “Letters on Education. Letter No. 4,” Vindicator, 17 Sept. 1830. 
majority in the colonial Assembly. Educational activists in the party were promoters of monitorial schooling before Lancaster arrived and secured a large grant of public money for him. Plans were afoot to make monitorial schooling the basis of the Lower Canadian system and, for a time, Lancaster seemed poised to occupy some important position in the field of colonial education. Yet his stay in the colony coincided with a dramatic radicalization of politics, propelled by election violence in Montreal in 1832 and by a large increase in immigration from England and Ireland, accompanied by epidemic cholera. Lancaster's involvement in both events cost him his support in the dominant party. As political conflict intensified and in the absence of any regular educational bureaucracy, the Assembly's school system degenerated into venality and corruption, and no colony-wide pedagogical model was adopted. By the time of the next major educational reform in 1841, monitorial schooling had fallen out of favour, and Lancaster, reduced to "a mass of obesity, unwieldy, and of feeble articulation... and objectionable habits," had been killed by a runaway horse on a New York street. ${ }^{5}$

JOSEPH LANCASTER (1778-1838), the son of a Non-conformist canesievemaker, was involved in charity schooling in London when he learned of a new method of instruction developed by the Anglican doctor Andrew Bell (1753-1832) at the Madras Asylum, a semi-official charity school for the orphaned sons of soldiers. Faced with large numbers of children to instruct and few resources, Bell had divided students into groups according to achievement, and enlisted some of the older children to instruct the younger. He adopted the method common to local Indian teachers of teaching to write letters in sand, and extended practices of "emulation" or competition for desired places in the school "class" that had likely been common in his own Scottish schooling. Refinements to his method eventually included the keeping of records of behaviour for each student and weekly model trials of offenders against the rules of the school by a jury of their peers. Bell and Lancaster were initially on friendly terms, but fell apart over the threat to Anglican orthodoxy posed by Lancaster's success in promoting a non-sectarian version of Bell's plans, and over Lancaster's increasingly loud claims to have been the inventor of monitorial schooling. ${ }^{6}$

Both versions of the method applied conceptions of factory discipline, military drill, accounting, and systematic organization to the schoolroom. Both introduced relatively new kinds of educational

5 Quoted in John Franklin Reigart, The Lancasterian System of Instruction in the Schools of New York City, Contributions to Education, No. 81 (New York: Teachers College, Columbia University, 1916), 18-19.

$6 \quad$ See Robert Southey, and Charles Cuthbert Southey, The Life of the Rev. Andrew Bell..., 3 vols. (London and Edinburgh: John Murray and William Blackwood \& Sons, 1845). 
apparatus, both prided themselves on the constant activity of all students, and both claimed to be able to teach young people to read and perhaps to write very rapidly and very cheaply. In Lancaster's Borough Road school, for instance, the students were grouped in twenties or thirties under the direction of a monitor and each student wore a number. The school consisted of two joined rooms, one 75 feet by 33, the other 40 by 14 , capable of accommodating up to a thousand students, who were instructed in eight achievement classes. One schoolmaster standing on a raised dais could teach all the students when they were seated facing him on long benches, or in their classes with monitors present. A system of signalling using raised poles distributed about the room with signboards on them, called "telegraphs," regulated activity: for instance, the posted letters "C.S." conveyed the command, "clean slates," which the students were meant to do in unison. Lancaster provided simple spelling, reading, and arithmetic lessons printed on large cards, and each class of students alternated between collective instruction with the entire school and group instruction with its own monitor. The monitors continually questioned students on their lessons, and any student who gave a wrong answer ceded his or her number, if it was higher, to the student who answered correctly. The monitorial school conducted on either the Bell or Lancaster model was a bustling place, with students moving repeatedly between the benches for collective instruction and the monitorial circle for smallgroup work. In Lancaster's school, there were parades of those performing best in their class, and of the best school class as a whole, and there were punishment parades as well. Both Lancaster and Bell devised elaborate systems of rewards and punishments and record-keeping, Lancaster especially encouraging students to accumulate tickets or tokens of good behaviour that could be exchanged for prizes, a practice Bell denounced as demoralizing. ${ }^{7}$ Carl Kaestle has suggested that, at least initially, monitorial schooling was likely amusing and enjoyable for students, although English working-class communities criticized its rote methods and rigid discipline. Moreover, its mechanistic character left little room for any kind of independent action on the part of students, monitors, or teachers. ${ }^{8}$

Lancaster's approach to schooling attracted the attention and support of leading liberal reformers from the late 1790s, including the Benthamite

7 See A. Bell, “Experiment in Education,” in D. Salmon, ed., The Practical Parts of Lancaster's Improvements and Bell's Experiment (1808; Cambridge: Cambridge University Press, 1932); J. Lancaster, Improvements in Education, as it respects the industrious classes (London: Darton and Harvey, 1805).

8 Carl F. Kaestle, ed., Joseph Lancaster and the Monitorial School Movement: A Documentary History (New York: Teachers College Press, 1973); Reigart, Lancasterian System; Brian Simon, The Two Nations \& the Educational Structure, 1780-1870(London: Lawrence and Wishart, 1974); Phillip McCann, ed., Popular Education and Socialization in the Nineteenth Century (London: Methuen, 1977). 
circle around the Edinburgh Review. ${ }^{9}$ The magistrate and political reformer Patrick Colquhoun was an early partisan and Lancaster received royal patronage in 1805, while Samuel Whitbread proposed as early as 1807 in Parliament that every parish should organize a monitorial school. Lancaster's backers and supporters promoted the formation of the Royal Lancasterian Institution in 1808, partly to offer a non-sectarian version of monitorial instruction on a national scale, but partly also to liquidate Lancaster's debts and to provide the systematic and economical day-today administration of existing schools for which his increasingly erratic character proved inept. However, the initial success of the project alarmed the Established Church, which countered first by engaging Andrew Bell to run a large school of his own, and then by organizing its own National Society for the Promotion of the Education of the Poor in England and Wales in the Principles of the Church of England. Drawing on Church resources, the Society rapidly outstripped the Royal Institution. A committee of management took control of the main Lancasterian school, the London Borough Road school, in 1811 and the Royal Institution became the British and Foreign School Society. Although Lancaster was engaged formally as master of the school in 1813, he fell out with his former associates and was encouraged or forced to resign in 1814. He undertook an abortive attempt to carry the school's subscribers with him and defended himself in print, but in 1818 he was convinced to leave for America in order to promote the system there.

In both New York, where Lancaster was connected to Thomas Eddy via Patrick Colquhoun, and in Quaker Philadelphia, where an act of 1818 made the monitorial method obligatory in schools for the poor, Lancaster repeated a version of the pattern of self-aggrandizement and paranoia that had led him to leave England. He was greeted with great enthusiasm, trumpeted his signal educational discoveries and his gifts to mankind, received financial support, ran or considered running a model school, failed to deliver any substantially new educational practice, took umbrage at some slight or failure on the part of his local allies, and left for the next place, where the pattern repeated itself. He spent time in Baltimore, Maryland, in Caracas, Venezuela, and in Trenton, New Jersey, before setting out to return to England via Montreal late in the summer of 1829. There, however, he fell ill and stayed long enough to discover another fertile field for the demonstration of his remarkable educational discoveries to local men of influence. ${ }^{10}$

9 For instance, Sydney Smith, review of “Outlines of a Plan for educating Ten Thousand poor Children, by establishing Schools in Country Towns and Villages; and for uniting Works of Industry with useful Knowledge. By Joseph Lancaster. 8vol. London. 1806,” Edinburgh Review (Oct. 1807): 61-73.

10 Kaestle, Joseph Lancaster; for New York, Riegert, Lancasterian System; for Philadelphia, David Hogan, "The Market Revolution and Disciplinary Power: Joseph Lancaster and the Psychology of the Early Classroom System," History of Education Quarterly 29, 3 (1989): 389-417. 
MONITORIAL SCHOOLING was well established in Lower Canada by 1829, and the political/religious conflicts that surrounded it in England reappeared in the colony, intensified by the presence of the Catholic Church. Notices of the method had appeared in the press in the first decade of the nineteenth century and it had been actively promoted by a committee of the Legislative Assembly, which printed 1500 copies of Lancaster's description of the method in 1815. A translation, produced by the Quebec prothonotary Joseph-François Perrault, had appeared in 1822 and later in the decade Perrault published other materials. ${ }^{11}$ The Anglican Bishop of Quebec stimulated the formation of diocesan branches of the Society for the Promotion of Christian Knowledge, through which, with the support of the Society for the Propagation of the Gospel, monitorial schools on the model of the National Society were founded in Quebec and Montreal before 1820. Anglican initiatives also included the establishment after 1818 of schools under the auspices of the Royal Institution for the Advancement of Learning, most of them rural, and the management committee of the Institution (which was in fact the Quebec diocesan committee of the SPCK) moved that no master would be subsidized by the Institution who had not been trained in Bell's Madras system. ${ }^{12}$

The four Lower Canadian Catholic Bishops were divided in their response to monitorial schooling. Bishop Plessis of Quebec, largely in response to Anglican and secular incursions against the Church's claim to a monopoly over education, supported the formation of the Société d'éducation de Québec in 1821, over which J.-F. Perrault initially presided, and was present for its first public examination. The Société offered Catholic free schooling on a model that combined elements of the Bell and Lancasterian systems, although it was comparatively underresourced, at least by the end of the decade. However, Plessis' associate, Montreal Bishop J.-J. Lartigue, and at least some parish priests opposed the Quebec Society as a Protestant Bible society in disguise, and their position was made more credible when the Society's president Perrault appeared at the head of the non-denominational British and Canadian School Society in 1823. The bishops soon denounced monitorial schooling as a dangerous form of liberalism. The method was seen as immoral, because monitorial schools often instructed boys and girls together, but it was also dangerous spiritually and politically because it encouraged students to read the Bible without the guidance of clergy. Mutual instruction by definition meant that students would instruct

11 Joseph-François Perrault, Cours d'éducation élémentaire à l'usage de l'école gratuite, établie dans la cité de Québec en 1821 (Québec: La nouvelle imprimerie, 1822); Manuel pratique de l'école élémentaire françoise (Québec: n.p., 1829); Tableaux de mots de deux syllabes à l'usage des écoles élémentaires du Bas-Canada (Québec: C. LeFrançois, 1830).

12 Spragge, "Monitorial Schools,” 47-61. 
themselves. To the hierarchy, such new forms of association threatened the basis of community and undermined the proper ends of education. ${ }^{13}$

Both the Anglican and Catholic projects encountered stiff competition from the colonial version of Lancaster's British and Foreign School Society. Before 1825, the British and Canadian School Society organized non-sectarian Lancasterian schools in the colonial cities and managed to draw some section of the school-age population away from the confessional institutions ${ }^{14}$ In addition to these versions of monitorial schooling, shortly before Joseph Lancaster's arrival in Montreal, J.-F. Perrault left the Quebec British and Canadian School Society and at his own expense constructed a large school that paired Lancaster's monitorial methods and apparatus with industrial training for both boys and girls. This school was widely publicized and trumpeted as a solution for pauperism in the colony, but Perrault offended both the majority in the Assembly by his support for the Crown, and the Catholic hierarchy by his insistence on admitting students of all religious denominations to his school. $^{15}$

As for Montreal itself, there was a vibrant and variegated educational economy in existence at the time of Lancaster's arrival that included two large monitorial schools. According to Jacques Viger's 1825 census of educational institutions, the British and Canadian School had 270 students in attendance, all subsidized, with a Mr. Hutchings teaching 196 boys, and Mrs. Chapman, 74 girls. Bell's method was employed at the National School, where the Holmes husband-and-wife team taught 222 boys and 116 girls. ${ }^{16}$ The arrival of the great man himself created a stir in educational circles.

13 Lartigue eventually attached an elementary school to l'École St. Jacques de Montréal. On the issues surrounding new forms of political association in this period, see Jean-Marie Fecteau, "État et associationnisme au XIXe siècle québecois: éléments pour une problématique des rapports État/société dans la transition au capitalisme,"’in Colonial Leviathan: State Formation in Mid-Nineteenth Century Canada, ed. Allan Greer and Ian Radforth (Toronto: University of Toronto Press, 1992), 134-62.

14 With minor variations, there are accounts of these events in L.-P. Audet, Le système scolaire de la Province de Québec, Tome 5 (Québec: Les Éditions de l’Érable, 1955); Jolois, Joseph-François Perrault; and Spragge, "Monitorial Schools."

15 See the detailed account of the school in Anon, Rapport d'un Québecois sur quelques écoles élémentaires du District de Québec (1834) (Canadian Institute for Historical Microreproductions [CIHM] \#21452); also Jolois, Joseph-François Perrault, 137-40 and passim. It is also worth noting that Montreal and Quebec both possessed an Infant School Society, which had the support of people from all political factions in the 1830s, and which ran schools closely modelled on that of Samuel Wilderspin; the Society was likely an offshoot of the British and Canadian School Society - at least that in Montreal shared space with the BCSS; see, for instance, Montreal Herald, 2 Oct. 1834; Montreal Gazette, 14 Nov. 1835. See also Phillip McCann, "Samuel Wilderspin and the Early Infant Schools,” British Journal of Educational Studies 14, 2 (1966): 188-204.

16 Musée du Québec, Archives du Séminaire, fonds Verreault-Viger, P32/022/052. 
THE LATE SUMMER of 1829 was a particularly auspicious moment for an educational promoter to arrive in Lower Canada. In the wake of the report of the 1828 imperial Commons Committee on Canadian grievances, extensive liberal reforms in colonial government, including a reconstruction of the oligarchic Legislative Council, seemed imminent. The contentious issue of control over colonial revenues, which had preoccupied the majority in the Assembly and which had been partly responsible for diverting attention from needed projects for physical and social infrastructure, seemed close to resolution. The refusal of the former governor Dalhousie to accept the election of the controversial patriote leader Louis-Joseph Papineau as Speaker of the Assembly was abandoned by his successor, Sir James Kempt, and henceforth all reasonable wishes of the majority in the Assembly, it seemed, were meant to be respected.

Moreover, the Canada Committee at least implied that the revenues from the Jesuit Estates, which the English Crown had appropriated at the Conquest from the French, would be placed under the control of the Assembly and directed towards educational purposes. It seemed that the occupation of the old Jesuit College as a military barracks would soon end and the Canada Committee urged the organization of a system of elementary education for the colony as a whole. After more than a decade of wrangling over elementary educational organization, in 1829 the two houses of the colonial parliament managed to pass, and the imperial government accepted, the Trustees School Act (9 Geo. IV cap. 46). The Assembly had repeatedly attempted to organize a monitorial school system throughout the colony; it now seemed poised to give effect to earlier plans. ${ }^{\$ 1}$

The Trustees School Act circumvented two earlier initiatives that had been squarely located within a religious investment of popular schooling. Under a law passed in 1801 (41 Geo. III cap. 17), but given effect only in 1818, the Anglican hierarchy managed schools funded through the Royal Institution for the Advancement of Learning. Attempts to enlist the support of the Catholic clergy for this body failed, as did attempts in the 1820s to establish a separate Catholic confessional committee within its management. By mid-1829, the Royal Institution was administering 79 schools with a total enrolment of 3,772, although its masters were well funded and were meant to employ monitorial methods. The Trustees School Act initially excluded Royal Institution schools from its provisions, while the Assembly continued to fund them,

17 See Peter Burroughs, The Canadian Crisis and British Colonial Policy, 1828-1841 (London: Macmillan, 1972). The complete text of the Canada Committee report is in Robert Christie, A History of the Late Province of Lower Canada. Parliamentary and Political. From the Commencement to the Close of its Existence as a Separate Province, 6 vols. (Montreal: Richard Worthington, 1866), Vol. 3: 184ff. 
but later revisions of the act made their funding conditional on coming under the management of elected trustees. ${ }^{18}$

The Trustees Act simply ignored the other piece of elementary school legislation in force, the Vestry School Act of 1824 (4 Geo. IV cap. 31). The Vestry Act had empowered parish vestries on their own authority to acquire and hold property in order to maintain one or more elementary schools. If a vestry lacked funds immediately to establish a school, the churchwardens were authorized to direct that a maximum of one-quarter of their revenues be diverted to create a school fund. Relatively few parishes had taken advantage of these provisions by 1829, the curés commonly having little enthusiasm for popular instruction, and the law being seen in part as a secular wedge in on-going struggles between clergy and laity over the democratization of the parish corporation (la fabrique). ${ }^{19}$

The Trustees School Act provided that any teacher of a rural school not under the control of the Royal Institution that was attended by at least twenty students was eligible for a legislative grant of $£ 20$ a year for three years, with a further 10 shillings a year for three years for each poor student in attendance to a maximum of fifty students, provided that it was certified that there were not less than twenty poor students. The grant was conditional on the management of the school by a board of five elected trustees at the level of the parish, but not on the raising of any school tax or school fees locally. An additional clause offered matching funds to a maximum of $£ 50$ for school construction and the purchase of a school site. The first version of the act excluded the clergy from participation in school management, although the clause was later modified, and the schools were later also placed individually under the management of three trustees. After 1830 many, if not most, trustee corporations included a curé, not uncommonly the only trustee who could sign his name.

The promise of a substantial sum of free government money generated a sudden and dramatic increase in the number of rural schools, especially in French-speaking areas of the colony. Two hundred and

18 National Archives of Canada (NAC), CO42/269, Gosford Commission Report, Appendix to General Report, Education, "Memorandum respecting the Board of Royal Institution established by the Provincial Act 41 Geo: 3 Cha: 17”; Audet, Le système scolaire, Tome I: Aperçu général (1950), 35-40.

19 Audet, Le système scolaire, Tome V: 69-90; Richard Chabot, Le curé de campagne et la contestation locale au Québec de 1791 aux troubles de 1837-1838 (Montréal: Hurtubise HMH Ltée., 1975); Christian Dessureault and Christine Hudon, "Conflits sociaux et élites locales au Bas-Canada: le clergé, les notables, la paysannerie et le contrôle de la fabrique,” Canadian Historical Review 80, 3 (1999): 413-39; Andrée Dufour, Tous à l'école: État, communautés rurales et scolarisation au Québec de 1826 à 1859 (Ville La Salle: Éditions Hurtubise HMH Ltée., 1996). For a discussion of the dismal failure of the attempt by the hierarchy to breathe new life into the Vestry Act in 1838 as a counter to Lord Durham's education commission, see Bruce Curtis, "State of the Nation or Community of Spirit? Schooling for Civic and Ethnic-Religious Nationalism in Insurrectionary Lower Canada," History of Education Quarterly 43, 3 (2003): 324-49. 
sixty-two schools took advantage of the act in 1829, 981 in 1830, and the numbers continued to increase, eventually surpassing 1,200 . Because the government did not spend to estimates but rather responded to claims, educational expenditure ballooned. The Assembly established a Permanent Committee that undertook to systematize and rationalize the administration of schooling, although, because school grants were administered by members of parliament individually as a form of patronage, its initiatives and recommendations for economy to the Assembly had little effect, especially as colonial political conflict intensified in the $1830 \mathrm{~s} .{ }^{20}$ Government funding created a dramatic increase in the demand for teachers. There were itinerant school teachers in Lower Canada, as in the other British North American provinces. In the towns, in the most prosperous rural areas of the colony, and in areas where some sort of culture of schooling had been established, teachers able to instruct more than the basics were able to make a living. ${ }^{21}$ On the margins of settlement the "friends of education" had to resort to various expedients to sustain teachers able to instruct even in the basics, and in many parts of the colony only the meanest forms of instruction were available. $^{22}$

The Catholic Church on the whole seems to have opposed anything beyond catechetical instruction for the vast majority of the population, with parish schools furnishing cantors and operating as recruitment devices for promising candidates for the priesthood. While the bishops attempted to incite parish priests to organize Catholic schools under the Vestry School Act, few did so at all or at all seriously. At times, the bishops clearly preferred no rural schooling to schooling not under Catholic control, and Bishop Lartigue went so far as to instruct one parish priest to refuse the sacraments to parents sending their children to a mixed school. ${ }^{23}$ Church opposition to more extensive schooling was largely effective in most French-speaking areas until the end of the 1830s, if not beyond. Forms of reading that were not closely confined to a religious idiom were denounced as "liberal.” Earlier attempts by itinerant teachers to establish schools on the Lancasterian plan in villages were sometimes

20 For a detailed, although unsympathetic, account, see NAC, RG4, B30, Dunkin to Buller, 10 June 1839 (the manuscript report of the education commission); see also Bruce Curtis, "Public Education and the Manufacture of Solidarity: Christopher Dunkin's Design for Lower Canada,” Histoire sociale/Social History 35, 70 (2002): 449-70.

21 See the discussion in J.I. Little, State and Society in Transition: The Politics of Institutional Reform in the Eastern Townships 1838-1852 (Montreal and Kingston: McGill-Queen's University Press, 1997), of the formation of local educational markets in the Eastern Townships before the passage of the 1841 School Act.

22 In the Val Cartier settlement, organized by John Neilson and Andrew Stuart explicitly as a demonstration project in American farming techniques (and as a speculative venture) in 1817-18, it was necessary to grant an older male teacher a house and a plot of land, in addition to fees, to provide a school even for the basics; see NAC, MG24, B1, vol. 191, Hurst to Neilson, 23 Oct. 1823.

23 Chabot, Le curé de campagne, 59-65. 
systematically undermined by the local priest. ${ }^{24}$ In village communities, with the possible exception of those places with a classical college, popular culture was not much caught up with printed text. Relatively few people could read ${ }^{25}$ French-language books, especially non-religious books, were in extremely short supply; and for the educated elite doctors, notaries, and minor officials - reading practice had itself been framed in fairly narrow and often religious terms. Of course there were many exceptions: curé J.-B. Boucher of Laprairie, for instance, a very active client of John Neilson's Quebec book business, or curé J.M.R. Barbier of the Berthier Academy, who encouraged his parishioners to form local associations to tax themselves for school provision, and who later promoted compulsory elementary education so that his academy might have a larger clientele. Several members of the Assembly were liberal intellectuals who maintained large libraries and some of the colony's classical colleges promoted liberal tendencies before the reaction of the 1830 s. $^{26}$

Nonetheless, the school reports generated by the Trustees Act reveal a marked set of differences between what was available to read in rural French-language and English-language schools, even those in which teachers aimed only at the basics. While a private market resulted in some diversity, English-language students, or students taught by Englishspeaking, or by the few French-speaking, Protestant teachers, were exposed to the range of secular school books, usually supplemented by the Bible and Testament, that were in common use elsewhere in northeastern North America. There was some kind of primer and speller, often Mavor's English Spelling Book, an arithmetic book, a reader, most commonly one of the many versions of Lindley Murray's The English Reader, a grammar book, and, less commonly, a book of elocution, a

24 Jolois, Perrault, 54n., reproduces the triumphant 1817 letter of the curé from Baie du Febvre to a French friend; 'Je fais ici ce que je veux. Si vous exceptez quelques impies qui travaillent à égarer mon peuple, et que je poursuis sans relâche dans tous leurs retranchements, tout le reste écoute ma voix et m’obéit. Les membres du Parlement, décidèrent de placer aux frais du gouvernement des ‘ écoles à la Lancastre `. Comme je ne suis pas Lancastrien et que je ne suis pas du tout libéral, je viens de donner la chasse à un homme libéral, qui était venu ici pour montrer d'une manière libérale. J’ai acheté l'emplacement qu'il venait de louer et, tout de suite, j'en ai acheté un autre proche de l'église, où il y a maintenant une école de garçons'.

25 I take exception to the claims in Michel Verrette, L'Alphabétisation au Québec 1660-1900. En marche vers la modernité culturelle (Québec: Septentrion, 2002), to the effect that the pattern of literacy in Lower Canada replicated that in most parts of Europe - an attempt in part to insert the literacy question into the long-standing debate over Quebec exceptionalism.

26 For Boucher, NAC, MG24, B1, 1, there is an ongoing correspondence starting with Boucher to Neilson, 18 March 1802; for Barbier, NAC, MG24, B1, 6, Barbier to Neilson, 10 October 1829; and more generally, Claude Galarneau and Maurice Lemire, Livre et lecture au Québec, 1800-1850 (Québec: IQRC, 1988); Yvan Lamonde, La philosophie et son enseignement au Québec (1665-1920) (Montréal: Hurtubise HMH, 1980). 
geography, history, or book in Latin. ${ }^{27}$ French-language students learned how to spell from some sort of Abécédaire, encountered the Petit catéchisme, and then typically some part of a standard selection of didactic religious books such as "L'Abregé de la vie de Notre Sauveur Jésus Christ, L' Histoire abregé de l'ancien Testament, moyen efficace de sanctifier la journée, visites au St Sacrement," or the still popular eighteenth-century "Instructions à la Jeunesse."28 Beginning and moderately advanced English readers could read for amusement, as well as for religious improvement. The great majority of French-language schools reporting under the school act offered, with rare exceptions, no non-religious reading material.

Any educational reformer interested in using the schools as a vehicle for creating general literacy, let alone for the promotion of notions of liberal citizenship, colonial self-government, political socialization, or workforce training faced a complex set of difficulties. Such was the case not simply because of paucity of resources and lack of administrative infrastructure, but also because of the effective confessional investment of practices of literacy. At the same time, the educational achievements and capacities of the French-Canadian population, especially the enfranchised rural peasantry, occupied an increasingly important place in colonial economic and political debate. Defenders of the colonial oligarchy argued in the early 1830s that the ignorance and religious superstition of the peasantry rendered its members unfit to govern themselves; colonial reformers, that the maintenance of popular ignorance was a strategy of imperial domination. Part of the promise of monitorial schooling to the reformers was that it seemed to offer a way to produce mass literacy quickly, cheaply, and in a non-sectarian context. ${ }^{29}$

LA MINERVE, the main paper of the patriote party, noted with interest on 14 September 1829 that the "Fondateur du système Lancastrien

27 The same pattern as in Upper Canada: see Bruce Curtis, "Schoolbooks and the Myth of Curricular Republicanism: The State and the Curriculum in Canada West, 18201850," Histoire sociale/Social History 6, 32 (1983): 305-29; and perhaps there is a deeper connection here between schooling in the two English-speaking populations, since the Upper Canadian General Board of Education supplied itself in the 1820s with schoolbooks through John Neilson's business, which, presumably, increased the supply of books in Lower Canada as well; see NAC, MG24, B1, 3, Strachan to Neilson, 16 April 1816, asking explicitly for costs for this list: " 1 . Tickets with the Alphabet of three different sizes 2. Pelham's Primer or Murray's First book 3. Mavor's Spelling book or Blairs reading lessons 4. Enfield's Speaker 5. Walker's Lessons 6. Burrens [?] Questions on the New Testament 7. A System of Arithmetic usual size.”

28 The collection of school reports is in NAC, RG4, B30; there are several hundred. 29 I take up this debate in passing in "Redécouper le Bas-Canada dans les années 1830: essai sur la gouvernementalité coloniale,” Revue d'histoire de l'Amérique française (2004): in press. 
d'Éducation mutuelle" had arrived in the city. Readers were reminded that his educational system had been the subject of discussion earlier in the press and in the Assembly, and it was announced that Lancaster would give a public lecture that evening in the Presbyterian church near the hay market, where a collection would be taken up. For his readers' benefit, editor Ludger Duvernay accompanied this announcement with some information about the Lancasterian system. Duvernay referred his readers to the French Baron Dupin's Forces productives et commerciales de la France, which claimed that Lancaster's method was short, easy, and better at exciting emulation than any other. Duvernay reproduced Dupin's anecdote of a rural priest whose flock had been given to spending its winter evenings in drink and debauchery until the system of mutual instruction created a passion for intellectual improvement, men and women studying apart. ${ }^{30}$

In fact, earlier that summer La Minerve had run a long series of letters from a French expatriate extolling the virtues of the Belgian Jacotot's educational system. The presence of Lancaster in the colony, at the moment when the Assembly had begun funding elementary schools, stimulated discussion of pedagogical methods. While it still had to begin by stating that public education was superior to private instruction, $\mathrm{La}$ Minerve raised the question of the comparative advantages of the systems promoted by Jacotot and Lancaster, claiming that educational methods that drew on the collective energy and used the passions of learners were best. The European press as a whole seemed to favour Jacotot, but the editor had only seen extracts describing the system and needed more information before making a definitive judgement. It seemed that the main difference between the two was that while Lancaster's system sought to economize the child's time by using the principles of simultaneity and reciprocity, Jacotot's sought to make efficient and effective use of the child's intellect. Still, when applied in the setting of a large school, the editor was persuaded that Jacotot's method 'dite ( émancipation intellectuelle '’ was quite similar to Lancaster's. ${ }^{31}$

The Jacotot method presented Lancaster with his first Canadian competitor. The Irish-Canadian reform paper Vindicator devoted most of an issue in August 1830 to a laudatory review by "Expositor" of Jacotot's system, which was held to redress the neglect of the aesthetic elements of learning common in other methods, including Lancaster's. As well, in contrast to Lancaster, Jacotot used a sight method of reading instruction, presenting the beginner with Fenelon's Telemachus and proceeding by word recognition. The book was held to offer all the intellectual, moral, and scientific knowledge a child would need, and "Expositor" claimed that the learner was led to discover everything for himself or herself,

30 La Minerve, 14 Sept. 1829. Duvernay claimed that this was a second Montreal visit for Lancaster, although Lysons-Balcon, "Lancaster, Joseph,” mentions only a visit to Quebec in 1828.

$31 \quad$ La Minerve, 3 Dec. 1829. 
without any adult guidance. Writing instruction began with the copying of sentences from Telemachus, and when the child had the first six books by heart, the foundation of education was said to have been laid. Jacotot's method was praised for its concentration on the development of the reasoning powers and the powers of judgment. Students wrote compositions and were examined as to their meaning, in contrast to Lancaster's method of teaching to write by dictation only. On the other hand, Jacotot taught grammar inductively, moving from usage to rules, rather than the inverse, and in this he shared with Lancaster an appreciation of methods denounced by others as "empirical." 22

In the winter of 1830, the legislature had voted Lancaster the sum of $£ 200$ to enable him to conduct a series of experiments in education. Vindicator added to the exposition of the Jacotot method the remark that since Lancaster had failed to reveal the results of his experiments, it was to be supposed that his method must resemble Jacotot's. Then, while the Jacotot discussion was running, a pair of Montreal teachers advertised that they were willing to teach the French language on Jacotot's plan, that they would soon be opening a regular school using the method, and, in the interim, they were willing to supply interested teachers with copies of Telemachus. ${ }^{33}$

Still portraying himself as the "Founder of the Royal Lancasterian System of Education," Lancaster responded indignantly to Vindicator's imputation, claiming to know as little of Jacotot as "the child unborn" and insisting that his thirty years' service in the advancement of education both removed any necessity of his relying on the experiments of others, and qualified him best to decide when his own experiments were sufficiently advanced to be shared with the public. ${ }^{34}$ However, this exchange prompted a series of letters sharply critical of both Lancaster and Jacotot from a correspondent signing as "P," and it is likely in response to this criticism that Lancaster produced the first Canadian number of his bombastic Gazette of Education and Friend of Man. ${ }^{35}$

"P" warned readers that public enthusiasm was not the measure of an educational "system" and that much more information was needed about the "infant mind" before the question of methods could be settled definitively. However, readers should be suspicious of claims of new educational discoveries, for these inevitably turned out to be the repetition of principles long since established; there was nothing new under the educational sun. "P" repeated part of the orthodox and romantic Anglican

32 Review of "A Compendious Exposition of the Principles and Practice of Professor Jacotot's celebrated System of Education, originally established at the University of Louvain, in the Netherlands. By Joseph Payne. London, 1830, R. Stephens,” by "Expositor," Vindicator, 20 Aug. 1830.

33 Vindicator, 27 Aug., 7 Sept. 1830.

34 Vindicator, 27 Aug. 1830.

35 Joseph Lancaster, The Gazette of Education and Friend of Man (Montreal: n.p, 1830). 
critique of Lancaster's method: "systematizers" were "egregious visionaries" whose "new-fangled notions of Education" would destroy the best memories of their youth, sacrificing the pleasures that generations had taken from being able to contemplate their copy-books and sum-books in later life "to the mean economy of Sand writing." In any case, Lancaster's pretentious styling of himself as the "Founder" of monitorial schooling was well known to be false; the system had been developed well before him by Andrew Bell, in whom "there is no pomposity."

There were two other objections raised by "P" to Lancaster's "system," and these were phrased explicitly as political objections, since the education of youth was "the cement" that held governments together. First, it was speculative to attempt to apply a "system" to young people whose circumstances were dissimilar "by Sect, Rank, Age, Habits, and Dispositions." This was an objection both to the project of common instruction as such and to its technical promise of success. This method worked against the natural order of things - "P" invoked explicitly the notion of "the great chain of being" - in which different groups necessarily received different forms of education. Second, gradation in social relations implied the necessity of gradation in education, with the learner passing carefully through a set of fixed stages of instruction. In the best system of education "there is no harlequinism, no hop-step-and a jump plan, from swaddling clothes, to Coat and Breeches, and then into the Chair of a 'System Professor',"' as was the case with Lancaster. ${ }^{36}$

"P" was equally critical of the method of "intellectual emancipation." The suggestion that schoolmasters were neglecting to develop students' love of beauty was true only for the minority motivated solely by financial considerations: if there were such in Lower Canada, they should be identified and denounced. "P" described Jacotot's argument that all one needed to learn was to be found in Telemachus as "the most barefaced nonsense I ever saw trumpeted before the public," and pronounced that the "“celebrated system"” was undoubtedly "the best that could possibly be invented to make a child a fool; to idiotize his little mind, and confound all his infant judgment." Again, "P”s objections were shared by many orthodox Anglican and Catholic observers. Jacotot's methods were faulty because they left the child to its own devices, while children were naturally evil and needed constant supervision and instruction in order to learn the proper way to conduct themselves. "Teaching a child to think for itself," and not constantly to look up to its guardians and superiors, was a "very dangerous system" that ultimately would lead the child to "reject the authority and authenticity, of The

36 Vindicator, 27 and 30 Aug. 1830. Notice that "P" is repeating much of the standard Anglican critique published in Robert Southey, The Origin, Nature, and Object, of the New System of Education (London: John Murray, 1812), and, I suspect, copying phrases from English authors. 
Book, to break from the Great Brotherhood, and thus ultimately dare to deny his all powerful, Merciful Creator.,"37

Lancaster now published a pamphlet in which he responded obliquely to this kind of criticism. "The public are well aware," began his Gazette of Education, "that the individual who now addresses them, is the inventor and founder of the Royal Lancasterian System of Education, and what they have heard of him for thirty years, they still find him, pursuing the same objects, with persevering undaunted step.” These objects were "Education. --- Education without proselytism." The bulk of the pamphlet recycled the testimonials from English noblemen about monitorial schooling that Lancaster had been flaunting in various venues for more than two decades. Some material, including an anecdote on King George IV and a set of "instructive enigmas," was more recent, but the pamphlet included very old miscellaneous material about the French Revolution and the supposed visit of the Egyptian Pacha's delegation to London to learn about Lancaster's system, along with the kinds of short anecdotes newspaper editors commonly used to fill space.

What was especially tailored to the Lower Canadian reform audience was Lancaster's rapid playing of the nationalist political card and his mysterious hints about the ways in which his new educational discoveries could further a national project: “'Can a Nation be born in a day'? As to Education Joseph Lancaster, hopes he is materially prepared to answer---Mentally or comparatively, and as to time 'It can' ." Or, that is, it could if Lancaster continued to receive funding to advance his work, on which matter his supporters had best act quickly, because now he was old and might be called to meet his maker at any moment. Should he die, he would certainly pass over with a sense of satisfaction at the work he had accomplished; yet strength rested with him still "to promote education throughout the British [P]rovinces of North America, but especially Lower Canada, ---To stir up the spirit of industry and emulation in doing good, is one more immediate object of my design, and for this purpose I distinguish between Education, and Education without Proselytism.” While Lancaster insisted he was no latitudinarian in religious matters, his system left doctrinal instruction to parents, priests, and ministers of religion.

Canadians could see from the pamphlet that they were fortunate. People all over Europe, in Egypt, and even in China were adopting the Lancasterian system while "in the mean time, JOSEPH, himself is now, not on the banks of the Nile, but of the River St. Lawrence, making two ears of corn for mental bread, grow where only one grew before.” It was true, Lancaster admitted, that French-Canadian students did not advance quite as quickly in his system as he had expected, because "they commonly converse in their own language with each other, and have therefore, not so powerful an auxiliary to their progress, as those who 
constantly hear English spoken and converse as well as learn to read in that language.” But this difficulty would soon be overcome. Again, Lancaster wrote, people might hesitate to grant him money because he kept the remarkable new discoveries he had made secret, yet he did so "not for monopoly; but with a determination to produce nothing to the public till time and repeated experiment shall have matured the undertaking." Contributors could rest assured that "in a short time, the demonstration of our Singular success in these and other departments will be exhibited to small, select and respectable companies, by special invitation only."

Lancaster claimed in a second pamphlet that he was in fact conducting a school in this period that he had begun in October 1829 after having "requested of the Committee of the Lancasterian School, the loan of eight ignorant boys of about six or seven years of age, who could spell words of two letters." Why the British and Canadian School of Montreal could not instruct its own ignorant boys in Lancaster's method he did not explain. Still, six weeks after Lancaster had them, they could all read any chapter in the Bible, and five of them had read the first chapter of John. ${ }^{38}$ Seemingly unaware that such instruction was indeed proselytism in Catholic eyes, Lancaster opened another school early in 1830, claimed to attract a large number of students, and held a public examination that attracted leading members of the local elite, including the Speaker of the Legislative Assembly, Louis-Joseph Papineau. Papineau was so impressed with the school that "after hearing the pupils read, and signing his name to a testimony in favor of the experiment, [he] laid down, unasked, a donation of twenty dollars." ${ }^{39}$ There were some problems with the school, Lancaster admitted, including irregular attendance and irregular admissions, but at a second examination held in 1831 he had 32 students and soon as many as 58 . Then, unfortunately, the cholera arrived in Montreal in the summer of 1832, forcing him to suspend the school for a time. It had just been praised in person by visitors from all political factions, according to Lancaster: Lord and Lady Aylmer, the defaulting Receiver General Sir John Caldwell, the Montreal Tory merchant Stanley Bagg, whose son attended the school, and Papineau himself.

Lower Canadian politicians were no more, but probably no less, astute than others to whom Lancaster had successfully made a pitch, and the Assembly itself was flush with cash. According to the conservative historian and contemporary participant in Lower Canadian politics, Robert Christie, anyone who had a dog-and-pony show could get a

38 John 1(i): "In the beginning was the Word, and the Word was with God, and the Word was God...” and so on, a lesson that at least had the advantage of presenting mostly words of one syllable, frequently repeated.

39 Joseph Lancaster, Report of the singular results of Joseph Lancaster's new discoveries in Education made at Montreal, from the commencement in 1829 to complete development of systematic principle in 1833 (Montreal: n.p., 1933); CIHM \#89895. 
subsidy from the Assembly, including a Quebec resident to whom it voted $£ 100$ to display his collection of curios. As Christie put it,

The assembly of Lower Canada were invariably liberal patrons of literature, science, the diffusion of knowledge and the arts. No man of the least pretensions to any of these, ever, it is believed, appealed to it in vain. On the contrary, in the desire to encourage merit in these branches its liberality was sometimes ill-bestowed and absolutely thrown away upon worthless adventurers and empyrics speculating upon its munificence. ${ }^{40}$

Lancaster appealed to the legislature for $£ 100$ in 1830 and on Papineau's motion, the Assembly doubled the sum and granted him £200. He received money again in 1831 and 1832: $£ 500$ in a period when rural school teachers were lucky to make $£ 50$ a year.

For a time, Lancaster's schooling activities united members of what were, or would soon become, opposing political factions in the colony. His correspondence was delivered to Louis-Joseph Papineau at least once by George Moffatt, who later became an important member of the virulently pro-British Montreal Constitutional Association. It ended up in John Neilson's personal papers, which suggests that Papineau passed it on to him as chair of the Permanent Committee on Education. Lancaster was alert to the importance of underlining the political promise of his educational work. In December 1831, he wrote to Papineau enclosing copies of the writing his students had been doing. The students were all between five and ten years of age and, Lancaster claimed, not only could read and copy, but could themselves write substantive answers to questions posed to them. More significantly, Lancaster suggested that his school was producing future clerks, for "our Boys of thirteen and upwards furnish Specimens of writing and Broad Sheets of accounts which would do credit to any public Institution in the world," a fact Lancaster claimed would be verified by P.-É. LeClèrc. ${ }^{41}$

At this moment, Papineau was trumpeting publicly the imperative necessity of education for all classes in Lower Canada and for producing French-Canadian clerks and administrators as part of the national project. In one of the few public speeches he seems to have devoted to educational matters, delivered in early May 1831, he argued that while general education was necessary to the operation of all liberal governments, it was especially necessary in Lower Canada, where the great majority of administrators came from abroad. Colonial governors could claim that there was not a sufficient supply of educated canadiens to fill administrative positions and Papineau maintained that imperial

40 Christie, A History of the Late Province of Lower Canada, Vol. 3: 287.

41 NAC, MG24, B1, 18, Lancaster to Papineau, 16 Dec. 1831. LeClèrc was soon to be, if he was not already, one of Papineau's serious political opponents. 
policy aimed to continue this situation by blocking local educational opportunities. Parents should be urged to encourage their children to go to school, so that the most talented among them might find a patron willing to send him on to one of the colony's colleges. The colleges themselves needed to be placed on a firmer legal basis. Papineau's measure of the success of his own party's educational policy was in part the spread of the mutual instruction common in the monitorial schools. As he put it,

C'est avec une vive satisfaction que je rappelle que le nombre d'écoles sur le plan de l'enseignement mutuel établies durant la même période [1829-31] est de plus de douze, qu'il a été introduit au séminaire de Québec, qu'il a commencé à passer des cités dans la campagne; que les écoles primaires fondées en vertu d'un acte récent de la législature provinciale, et qui ne comptaient pas quinze mille enfans, il y a deux ans, en comptent aujourd'hui près de cinquante mille. ${ }^{42}$

Lancaster's prospects were also brightened by the support of John Neilson, the Quebec printer, newspaper editor, and capitalist who chaired the Assembly's Permanent Committee on Education until his break with the patriote party in 1834. Neilson had been involved more or less actively in the Quebec monitorial school societies from the outset, and he remained a life-long enthusiast of the method. When he travelled to England in 1835 as a representative of the Quebec Constitutional Association, he carried with him a letter of introduction to Henry Dunn, the director of the BFSS's Borough Road School. It was probably Neilson as well, as a member of the Board of Directors of the Quebec Normal School, who was responsible for charging the abbé Jean Holmes to inquire into the prevailing European opinion of monitorial schooling during the latter's trip to recruit Normal School masters in 1836-37. ${ }^{43}$

Neilson was one of nineteen members of parliament named to inspect the schools under 1831 amendments to the 1829 School Act . He visited the four eastern counties of Kamouraska, L'Islet, Rimouski, and Bellechasse in July and August 1831 to get a sense of the operations of the School Act and to consider needed improvements. He was quite sanguine about the quality of instruction in these counties and claimed that, although there were more men than women teaching, women

42 Quoted in Yvan Lamonde and Claude Larin, eds., Louis-Joseph Papineau. Un demi-siècle de combats. Interventions publiques (Montréal: Fides, 1998); the entire speech is 188-94. Chabot, Curé de campagne, $116 \mathrm{ff}$. shows that curé Chartier had proposed to introduce the Lancasterian system into the Collège de Ste-Anne, which he directed. Chartier was in close correspondence with Papineau.

43 NAC, MG24, B1, 8, William Stowe to Henry Dunn, 15 April 1835; Musée de la Civilisation, Fonds du Seminaire de Québec, Polygraphie 16, d, e \& f, Extraits du Régiste de l'Ecole Normale du District de Québec, 11 April 1836. 
teachers were best suited to instruct elementary school children and an ample supply of them had been produced by the convent schools. Yet, even as he praised the general quality and conduct of the teachers, he disqualified 20 per cent of them.

Neilson was also sharply critical of several practices made possible by the 1829 act which he held were bringing schooling into disrepute. In addition to simple patronage practices, such as the tendency of inhabitants in some areas to hire teachers who were relatives and friends, or to hire a husband and wife or brother and sister, lodge them in a schoolhouse built at public expense, and claim two school grants for them, Neilson pointed to a funding flaw in the 1829 act. The 10 shillings for each poor scholar beyond the £20 offered for a school with twenty students in attendance was interpreted to mean that any school with only twenty students was entitled to $£ 30$ from the legislature, provided that no fees were collected. Many, if not most, schools thus received no financial support from the community; wealthy parents did not feel compelled to pay fees; and Neilson claimed that many thought \$6 a month ample compensation for a female teacher. Small schools proliferated. Neilson held that parish residents divided large schools in order to claim more grant money, and students too old to attend, or who never attended, were entered on the roll to make up the minimum number of twenty. He dealt with these practices in his own jurisdiction by overseeing a plan to divide counties into regular school districts, each district with a school-age population of about one hundred within easy walking distance of a school. To instruct one hundred students, teachers would have to adopt some version of the monitorial method. As Neilson put it,

Un Instituteur peut avec facilité diriger une Ecole élémentaire de cent enfans et au delà, lorsqu'il a plusieurs Ecoliers qui ont déjà fait quelque progrès, et qui sont en état de lui aider à enseigner par classes distinctes; les meilleurs écoliers sont ordinairement chargé de ce devoir, et c'est une chose bien démontrée que ceux qui le remplissent, en enseignant ceux de leur propre classe, font des progrès beaucoup plus rapides que s'ils n'étaient pas employés de cette manière. D'ailleurs il est assez ordinaire que les maîtres exemptent de payement ou encouragent de quelqu'autre manière les écoliers qui les assistent ainsi. ${ }^{44}$

For the great mass of the agricultural and artisanal population, Neilson held that schooling should end at age nine: before that, children were a nuisance when at home; by that age they could acquire all the training in reading, writing, and arithmetic they would need. Women's natural gifts

44 Musée de la Civilisation, Fonds du Séminaire de Québec, Polygraphie 42, no.20 H, Rapport du Visiteur d'Ecole pour les Comtés de Bellechasse, L'Ilet, Kamouraska et Rimouski, and addressed to "L'Honorable Chambre d'Assemblée du Bas-Canada, assembleé en Parlement,” 21 Aug. 1831. 
in the arts of dealing with such young children meant they were likely to be the best teachers, and if education was to become general, it would have to be cheap.

In part because of Neilson's influential report, and from investigations before the Permanent Committee as to needed reforms, the 1832 School Act (2 Will. IV cap. 26) made a serious effort to systematize elementary educational organization and provision in the colony. The troublesome funding arrangements were altered, with school districts now empowered to conduct a boys' and a girls' school out of a set grant. More pertinent to my purposes (and later more controversial) were clauses for consistent school management and the creation of a school prize fund to be administered by county school visitors, who would award the student making the best progress in any school the sum of 10 shillings. Systematization implied the adoption of a pedagogical system, and for Neilson at least, that system should be monitorial. The prize fund was to encourage "emulation," but it could also be seen as a way to support student monitors out of the parliamentary grant. School inspection was also reorganized according to this act.

Shortly before leaving the colony, Lancaster sent to Papineau, who sent it on to Neilson, a set of recommendations dealing with many of the issues raised in Neilson's report and addressed by the 1832 act. The recommendations were in the form of short autograph essays, entitled "On Medals and School Premiums \&c"; "On the visitation of Schools and objects of visitation, with the points, which, require the most particular notice by visitors"; and reports "On circulating Schools," on the "Reward or Income of teachers," and finally, "On Female Education." 45 The essay on medals suggested that the best students, monitors, and teachers be awarded medals of steel, white metal, and silver respectively upon examination by the school visitors. The medals should be conferred at a public ceremony, and medal winners should be encouraged to wear them daily for seven weeks, and at all festivals and feast days thereafter.

Lancaster claimed that "perhaps there is no person living on the continent of Europe and America who has en passant, or repeatedly visited more Schools than I have done.” He made a point of dwelling on the bright side of things in his own visits, and stressed that it was possible "by a judicious system of visitation inspection and reward to cheer up the whole horizon of Education in this province.” Despite the ambitious title

45 See NAC, MG24, B1, 8, in the file for June, 1833. Lancaster did comment in one section of the manuscript, "if I could be favored with a copy of the acts of parliament now in existence for education I may be able to suggest something more effectual," which might imply that these suggestions were made after the passage of the $1832 \mathrm{act}$. However, the cover letter itself is not clearly dated; and by June 1833, Lancaster had left the colony. He seems to have been seeking parliamentary monies for things he had done earlier. In any case, whether he was proposing things that were later embodied in the 1832 act, or reacting to its provisions, the manuscripts constitute a set of attempts to adapt his system to Lower Canadian conditions and to bolster his position as an educational authority. 
of this essay, there was little actual detail as to what school visitors should observe, and no comment on school record-keeping or reporting, although Lancaster did claim that "the statistics of Education will another year exhibit the means of estimating the quantity of ignorance extinguished and the degree of elementary knowledge gained in proportion to the advances of money made by parliament." In his brief remarks on "circulating schools," Lancaster suggested that the best way to service those areas too remote to sustain a regular school was to establish stations where school teachers would reside between six and eighteen months, offering instruction both to children and adults. As well, in order to address the difficulty caused by low pay for teachers, which he claimed kept the best characters out of the occupation and demoralized the rest, Lancaster suggested that parents donate land which would be made available to teachers upon retirement. Finally, his brief remarks on "Female Education" were entirely devoted to the problem of providing instruction in needlework for girls. He assumed that girls and boys would frequently have to attend school together, and he seems to have assumed that their teacher would thus be male. To remedy this problem, itinerant needlework teachers, "widows or women advanced toward the meridian of life," should be engaged and sent around the countryside. He promised more on this subject at some future date, but concluded, "perhaps, it will be readily admitted, that except reading there is no attainment, of more importance to females than their universal instruction in needlework whether one consider it as the cause of comfort and cleanliness, or its tendency to industry and civilization.”

In fact, there was little of any novelty in Lancaster's hand-written treatises; most of the proposals had been made by him or by Andrew Bell in print repeatedly since the first decade of the nineteenth century. Perhaps the proposals for circulating schools and for a teacher's retirement fund in land were tailored to Lower Canadian conditions, and Lancaster also claimed to have modified his system of instruction so that it could be used in small rural schools. ${ }^{46}$ Still, as revisions to the 1829 Trustees School Act led in the direction of a more clearly co-ordinated and systematically administered school system, Lancaster was positioning himself as an educational expert worthy of both the ears and the purse of the Permanent Committee of the Assembly.

REASONABLY well established in Montreal, seemingly enjoying the esteem and support of politicians from all factions, and subsidized by the legislature, Lancaster must have thought his prospects seemed bright before the Montreal West Ward election in April and May 1832. ${ }^{47}$ The

46 Lancaster, Report of the singular results.

47 For an account of the election, see France Galarneau, "L'élection partielle du quartier-ouest de Montréal en 1832: Analyse politico-sociale," Revue d'histoire de l’Amérique française 32, 4 (1979): 565-84. 
election was tightly contested, opposing Daniel Tracey, the radical editor of the Vindicator newspaper, who had recently been imprisoned by the Legislative Council for contempt, against the Tory merchant Stanley Bagg, and there was a pitched battle for control of the poll that continued for several days. Exact accounts of events differ, according to which faction was reporting them, with Tracey's supporters claiming that Bagg's hired "bullies" were beating up reform voters and others claiming that when the magistrates called in the garrison troops to separate the two parties, Tracey's supporters pelted them with stones. In any case, on 21 May the troops opened fire on the election crowd, killing three patriote electors and wounding others. Much of the population was outraged. The bodies were taken to Place d'Armes and when Papineau and the other patriote leaders, Cherrier, de Bleury, and Lafontaine, attempted to discover, from the commanding officer, who had given the order to fire, he refused to answer and cannon were brought to the square to menace the growing crowds. Papineau himself claimed that he was roughed up in the street by Bagg's toughs as he made his way home. ${ }^{48}$ The attempt of a coroner's jury to convict the commanding officer of murder charges was blocked by the Crown, and Papineau's direct intervention was declared by the governor, Lord Aylmer, to be an abuse of his official position as Speaker of the Assembly. ${ }^{49}$ The events are commonly seen as a turning point in Lower Canadian politics, alienating many patriote politicians irrevocably from the Crown, which now seemed willing to use force of arms to keep its oligarchic allies in power, and deepening the gulf between opposing parties in Montreal.

Lancaster voted for Bagg, whose son was one of his students. He claimed to have had no interest in the election, but to have pledged to vote for Bagg as someone he knew, and, once pledged, to have been honour bound to do so. Lancaster claimed that Papineau, Jacob de Witt, and L.-H. Lafontaine insisted that he not vote for Bagg, with de Witt and another man threatening to withdraw their children from his school if he did so. He maintained that D.-B. Viger also came to see him and warned him not to vote for Bagg. Papineau, by contrast, denied any attempt to influence Lancaster. As he put it to John Neilson, he had had no involvement in the election events, beyond expressing his opinion when asked: 'Mr Lancaster seul est venu me parler du sien et me demander le mien, que je lui ai donné. Un Citoyen Anglais est venu me demander s'il était qualifié à Voter. Je lui ai dit que oui et ne lui ai pas demandé pour qui il le ferait... ${ }^{50}$ Still, Lancaster recounted that, walking home from the Public Library one afternoon, he was accosted by Adam Ferguson, editor of the Tory Montreal Herald, and Robert Armour, Jr., whose father edited the Gazette, carried off to the poll and urged to respect his promise to

NAC, MG24, B1, 7, Papineau to Neilson, 6 June 1832.

Christie, History of the Late Province, vol. 3: 389-406.

NAC, MG24, B1, 7, Papineau to Neilson, 6 June 1832. 
vote for Bagg. Lancaster claimed that Lafontaine made a speech there that seemed to imply that if Lancaster voted for Bagg, the parliamentary subsidy for his school would end. Yet, having no choice but to respect his word, Lancaster voted for Bagg. ${ }^{51}$

There was much missing from Lancaster's account of his political experiences in Montreal. Was it to Lancaster that La Minerve was referring when it reported in August 1832 that an individual was advertising in the press his intentions of publishing a pamphlet on the Montreal election and that he had been using the threat of publication in attempts to blackmail some leading citizens? ${ }^{52}$ Probably. At least Lancaster neglected to discuss in any detail his controversial involvement in the cholera epidemic that swept through Montreal in June and July 1832, causing a great many deaths and widespread panic in the population. The epidemic was seen in some nationalist circles as a direct result of the encouragement of Irish pauper immigration by the English government and by its oligarchic colonial allies.

Lancaster associated himself with the mysterious cholera doctor Stephen Ayres - "docteur charbon," as La Minerve dubbed him - who claimed to have a treatment for the disease capable of curing eight out of ten affected cases. Tall, thin, ill-dressed, with piercing eyes and long black hair tied behind with a ribbon, Ayres was said to have appeared suddenly in Montreal at the height of the epidemic, in a ox-cart drawn by two bony oxen. He established himself in an office next door to Lancaster's house at Craig and Bleury Streets and advertised his willingness to treat all and sundry free of charge. The press, including the reform Vindicator, claimed that his remedy, based on charcoal, maple sugar, and hog's lard, was indeed effective, and it seems his presence helped calm the panicked populace. ${ }^{53}$

51 Lancaster, Report of the singular results.

52 La Minerve, 9 Aug. 1832.

53 In the Vindicator, 22 June 1832, "Treatment of Cholera Morbus by Stephen Ayres Two table spoonsful of finely powdered charcoal, two of maple sugar pounded, (or in default thereof [demarara? illegible] sugar may be used) and a like quantity of hog's lard, are intimately mixed together, to these are added in certain (I believe in most) cases a cinnamon dose and a half of rhubarb. One half of this mixture is given to the patient at once. If he has the cramps or spasms, he is rubbed over with a lye of wood ashes and water, as hot as can be borne, but not over strong. In the event of its proving ineffectual, if the spasms continue or increase, very hot brandy, of the best kind, is substituted for the lye. If the patient vomit after the first dose of charcoal, \&c. the second is administered after the lapse of half an hour. After this treatment has been used, \& as soon as the patient is a little recovered, he is to take a plate of bean soup, made with very fat pork, and to drink water in which has been quenched a live coal of maple wood. He may also take very strong chocolet with a little milk, and a wine glass full of leaven or baker's yeast will help in maintaining the functions of the stomach. A very considerable number of cures are said to have been performed by this man." See also the account in Susanna Moodie, Roughing It in the Bush; or Life in Canada (1852; Ottawa: Carleton University Press, 1988), 42-43. 
His treatments, however, were controversial. Lancaster seems to have become his promoter and defender, and found himself severely criticized in early August for his activities in relation to the aboriginal population at Caughnawaga, where the epidemic had caused 70 deaths among 180 cholera cases. The mission, run by Father Marcoux, had earlier been inspected by a Lieutenant Colonel MacKay, who reported that accommodations were clean and that the population was receiving all possible care. Shortly after MacKay's visit, Ayres was briefly at the mission and Lancaster, in another number of the Gazette of Man (which seems not to have survived), proclaimed that Ayres had cured many people who were being neglected by the missionary. Father Marcoux was outraged by Lancaster's claims and wrote to La Minerve to denounce his pamphlet as the sort one might expect from "un enfant de Fox." Marcoux said that as far as he knew, everyone severely affected by cholera at Caughnawaga had died from it and, while he had observed Ayres' treatments when that person was on the station on 2 July, without approving or disapproving them, there were in fact no cases when Ayres was present. The least one could say was that Ayres had not killed anyone, but Marcoux had no reason to believe Ayres' method worked.

Lancaster apparently had stated that many Indians had been saved from cholera by a shipment of Dr. Ayres' "cholera suits.” Marcoux replied that while Ayres did distribute some tattered pieces of cloth, which "quelques imbéciles" believed would protect them from cholera, many subsequently died from the disease. As far as Marcoux was concerned, the high mortality rate at the mission was due to "la facilité qu'ont les sauvages de se procurer des liqueures fortes chez tous les détailleurs de boissons. ${ }^{~} 54$ La Minerve refused to translate and publish Lancaster's reply to Marcoux, which had appeared in the Tory Herald, ${ }^{55}$ describing it as "une diatribe grossière" against a member of the clergy to whom the country was indebted. La Minerve commented that this insult to the clergy was all that had been lacking from Lancaster, who had been trying for weeks to dictate to the Board of Health, the health commissioner, and the editor of the official Gazette. This was how he repaid the support and kindness he'd received since arriving in the country! But there was worse. The editor lamented that the honest and moral citizens of Montreal had been deeply insulted by Lancaster's farcical parading of Indians from Caughnawaga to the city in a carriage, the American flag flying, with Lancaster proclaiming they were come to denounce the lies of the missionary Marcoux. La Minerve reported that Lancaster debauched them with drink in the city's inns.

Having aligned himself clearly with the ultra-Tory minority in the colony and having alienated some leading sections of the French-

54 La Minerve, 30 July 1832. Notice also the letter to the editor of 23 Aug. 1832 from Dr. J.-B. Meilleur, future Chief Superintendent of Education, observing that in his parish Ayres' cholera cure did not seem to work, and expressing his entire support of Marcoux. 55 The relevant issue of the Herald seems not to have survived. 
Canadian majority in the Assembly, Lancaster did not apply for a further grant from the legislature. Instead, in April 1833 he applied directly to the governor for aid and denounced his treatment at the hands of the Papineau faction in a further piece in the Herald, which La Minerve reported as bearing the title "Thanks and No Thanks to Papineau." Lancaster was all wounded innocence in his appeal to Lord Aylmer. He had been threatened during the Montreal election by Jacob de Witt, Bruneau, and Lafontaine. And there was "Speaker Papineau himself, urging me to vote for Tracey and threatening me on the contrary, insulting my feelings as a Briton, and finding that I could not and would not break my word lamenting that he could not "convert me [to a] Canadian citizen'.” His school remained as effective as ever and Papineau himself had been praising Lancaster's educational system for more than twenty years. In the name of "British freedom" Lancaster concluded that "I have done too much for mankind to be friendless in the world, nor do my friends intend their friendships to chain my freedom or buy my birthright!"56

La Minerve took a very different view in a long post-mortem on Lancaster's stay in Canada, published on 17 May 1833, using it as a talking piece to defend the patriote majority in the Assembly against Tory pretensions and to portray French-Canadians as the patient friends of liberty. Here was an Assembly abused and attacked at every turn by the enemies of liberty, and how did it respond? It emptied the public chest to build roads for isolated English settlers, it supported their social institutions, and it showed its generosity in welcoming Lancaster, one of Britain's “gloires exilées.” None of them knew Lancaster personally, but he never had stauncher defenders than this French-Canadian population which he was now abusing. They took him on faith. They did not listen to those who claimed his "experiments" were fraudulent; they knew he had been persecuted by enemies of the human spirit; they appreciated the losses he had incurred in spreading his system around the world. The French-Canadians even went so far as to defend him against claims that Andrew Bell was the true inventor of monitorial schooling, arguing that honour was due to he who spread the system. When Lancaster appealed for money, the Assembly responded. When his experiments were not completed, they gave him more money, even providing him with a printing press. And when he proved incapable of economical management, they concluded he was too busy with work to do otherwise.

Lancaster repaid these kindnesses by using the political differences around the 1832 election to his own ends. He published what he claimed were private conversations with leading men in the newspapers. He flirted with blackmail. He threatened and insulted those who supported him. It was well known that he had not applied to the legislature for further aid,

56 Lancaster to Aylmer, 6 April 1833, cited in Spragge, "Monitorial Schooling.” Again, the Herald number seems not to have survived. 
but La Minerve claimed that, had he applied again, the generous majority would have overlooked all his excesses and would have made a further grant in recognition of his contributions to education. It was a sad affair. ${ }^{57}$

JOSEPH LANCASTER's stay in Montreal lasted from September 1829 until May 1833, a relatively long period for an itinerant life such as his after his departure from England in 1818. Monitorial schooling was already well established in the colony at his arrival, and the schools he claimed to have conducted could never have competed with the large institutions in Montreal run by the British and Canadian School Society and the National Society. Still, he seems to have managed to convince important members of both the French- and English-Canadian elites that his was the school their sons should attend, and that he was an educator worthy of support from the legislature. For a time, Lancasterian schooling served as a direct link between men who would later oppose one another by force of arms. Important “friends of education,” such as John Neilson, took it for granted that mutual or monitorial instruction was the model for Lower Canadian schools, both rural and urban. Louis-Joseph Papineau took the spread of mutual instruction to be one measure of the success of the Assembly's educational policy and a sign of national progress for FrenchCanadians. Lancaster was moved to address some of the interesting administrative reforms to rural schooling under way in the early 1830 s with some modest and mainly shop-worn suggestions. Still, he may well have had some influence on revisions to the 1829 School Act.

Yet, after the temporary lull in the struggles among colonial political factions caused by the promise of reform in the 1828 report of the imperial Canada Committee, educational questions once again became intensely political questions. An ally of the Crown, such as JosephFrançois Perrault, received irregular and relatively minor grants from the patriote Assembly, despite his sophisticated industrial/monitorial schools, which, unlike Lancaster's school, actually attracted very large numbers of students. Lancaster received a comparatively generous subsidy as long as he managed to present his educational system as non-sectarian and capable of rapidly training a colonial professional class, and before his political allegiances were clearly defined. Given his past inability to sustain the consistent, day-to-day effort required actually to manage a substantial school, it is unlikely that Lancaster himself would have had a significant direct personal involvement in Lower Canadian schooling over the longer term. His political choices and personal instability ensured that his direct influence on colonial educational policies would remain slight. 